\title{
METHODS OF COMPLEX ASSESSMENT OF NATURAL AND ANTHROPOGENIC PRESSURE FOR WATER RESOURCES IN CENTRAL ASIA - KARATAL RIVER CASE STUDY
}

Zhumakhan Suleimenovich MUSTAFAYEV, Department of Water Resources and Melioration, Faculty of Forest, Land and Water Resources, Kazakh National Agrarian University, 050000 Republic of Kazakhstan, Almaty, Abaya avenyue 8, z-mustafa@ rambler.ru Jozef MOSIEJ, Department of Environmental Development Poland; Faculty of Civil and Environmental Engineering, Warsaw University of Life Sciences-SGGW, PL 02-787 Warszawa, Nowoursynowska st. 166, Poland, jozef_mosiej@sggw.pl (corresponding author)

Lya Tobazhanovna KOZYKEEVA, Department of Water Resources and Melioration, Faculty of Forest, Land and Water Resources, Kazakh National Agrarian University, 050000, Republic of Kazakhstan, Almaty, Abaya avenyue 8; aliya.kt@yandex.ru

Kurmanbek ZHANYMKHAN, Department of Water Resources and Melioration, Faculty of Forest, Land and Water Resources, Kazakh National Agrarian University, 050000. Republic of Kazakhstan, Almaty, Abaya avenyue 8, mr.aidynbek@ mail.ru

\begin{abstract}
Development of the national economy in the Karatal basin river is characterized by the progressive involvement and development of the resource potential of natural landscapes, the current rate of utilization of which greatly enhances the anthropogenic impact on the natural environment. A significant impact on the formation of the ecological environment of natural landscapes is provided by the rural and water sectors, as well as by industrial facilities related to processing and mining. At the same time, on the one hand the economic activity of the man in the catchment areas of the river basin gives a certain positive effect, and on the other hand, it is accompanied by an unavoidable set of negative ecological consequences that complicate ecological situations in various ranks of natural systems. Such negative natural and man-caused process in human activity occurs as a result of inadequate knowledge of the regularities of interaction between natural and anthropogenic factors, about the processes developing in the natural environment in complex watershed management, which is one of the obstacles on the way to the creation of ecologically sustainable cost-effective water catchment systems.

Scientific interest to the assessment of the ecological state of the catchments of rivers and the problem of their complex development have been appeared relatively recently which is explained by the increase in modern conditions of anthropogenic load on the catchment areas, the need to assess the impact of such pressures on the ecological stability of catchments and the emergence of the problem of ensuring the sustainable function of catchments. The catena concept was developed to analyze the regular variability of soil on the slope. The example of this approach consists first in a structural component, the recurring pattern of certain soils in a landscape transects in which every chain element has its place in the chain, a soil has it in a landscape areal.

The object of the research is the catchment basin of the Karatal river with a length of $390 \mathrm{~km}$, an area of 19.1 thousand $\mathrm{km}^{2}$, which is formed by the merger of three rivers called Tekeliaryk, Chadzha and Kora, sources which are at an altitude of 3200-3900 m. The initial $160 \mathrm{~km}$ is mountain character, from the Zhungarian Alatau and below the confluence of Kara and Chizhe River overlooks a wide intermountain plain. Other tributaries are Kara, Terekty, Laba, Balykty, Mokur and the most abundant is Koksu. After the confluence of the tributary of the Koksu River, Karatal flows through the sandy desert of the Southern Balkhash. At a distance of $40 \mathrm{~km}$ from the mouth, the river has a delta area of $860 \mathrm{~km}^{2}$. According to long-term observations, the average annual discharge of the Karatal River in the Ushtobe section is $66.7 \mathrm{~m}^{3} / \mathrm{s}$ or $2.1 \mathrm{~km}^{3} /$ year.
\end{abstract}

Keywords: geomorphological analysis, indicators of anthropogenic loads, hydrological-climatic assessment, landscape melioration.

\section{INTRODUCTION}

Development of the national economy in the Karatal basin river is characterized by the progressive involvement and development of the resource potential of natural landscapes, the current rate of utilization of which greatly enhances the anthropogenic impact on the natural environment. A significant impact on the formation of the ecological environment of natural landscapes is provided by the rural and water sectors, as well as by industrial facilities related to processing and mining. At the same time, on the one hand the economic activity of the man in the catchment areas of the river basin gives a certain positive effect, and on the other hand, it is accompanied by an unavoidable set of negative ecological consequences that complicate ecological situations in various ranks of natural systems. Such negative natural and mancaused process in human activity occurs as a result of inadequate knowledge of the regularities of interaction between natural and anthropogenic factors, about the processes developing in the natural environment in complex watershed

Copyright (C) 2017 The Authors. Published by Aleksandras Stulginskis University. This is an open-access article distributed under the terms of the Creative Commons Attribution License (CC-BY 4.0), which permits unrestricted use, distribution, and reproduction in any medium, provided the original author and source are credited. 
management, which is one of the obstacles on the way to the creation of ecologically sustainable cost-effective water catchment systems. The catena concept was developed to analyze the regular variability of soil on the slope. An example of this approach is based on the structural component, the soil in the landscape.

Scientific interest to the assessment of the ecological state of the catchments of rivers and the problem of their complex development have been appeared relatively recently (Golovanov et al.,2006; Aidarov, 2007; Khafizov, 2009; Burlibaev, M.Zh.; 2014, Kaca, 2017; Ryden et al., 2017; Yunussova and Mosiej, 2016), which is explained by the increase in modern conditions of anthropogenic load on the catchment areas, the need to assess the impact of such pressures on the ecological stability of catchments and the emergence of the problem of ensuring the sustainable function of catchments.

\section{RESEARCH OBJECT AND METHODS}

\section{Materials and methods}

The object of the research is the catchment basin of the Karatal river with a length of $390 \mathrm{~km}$, an area of 19100 $\mathrm{km}^{2}$, which is formed by the merger of three rivers called Tekeliaryk, Chadzha and Kora, sources which are at an altitude of $3200-3900 \mathrm{~m}$. The initial $160 \mathrm{~km}$ is mountain character, from the Zhungarian Alatau and below the confluence of Kara and Chizhe River overlooks a wide intermountain plain. Other tributaries are Kara, Terekty, Laba, Balykty, Mokur and the most abundant is Koksu. After the confluence of the tributary of the Koksu River, Karatal flows through the sandy desert of the Southern Balkhash. At a distance of $40 \mathrm{~km}$ from the mouth, the river has a delta area of $860 \mathrm{~km}^{2}$. According to long-term observations, the average annual discharge of the Karatal River in the Ushtobe section is $66.7 \mathrm{~m}^{3} / \mathrm{s}$, or 2.1 $\mathrm{km}^{3} /$ year (Zhanymkhan et al., 2016).

The concept of a catena was developed in order to analyse the regular variation of soils across a slope. The example of this approach consists first in a structural component, the recurring pattern of certain soils in a landscape transects in which every chain element has its place in the chain, a soil has it in a landscape areal. The concept of a catena was developed in order to analyze the regular variation of soils across a slope. The example of this approach consists first in a structural component, the recurring pattern of certain soils in a landscape transects in which every chain element has its place in the chain, a soil has it in a landscape (Sommer et al. 2000; Young, A. 1972).

The integrated assessment methodology of natural and anthropogenic load of the catchments of the Karatal River basin, taking into account the multidimensionality of the problem, adopts the entire set of existing methodological approaches to environmental management systems, where the catchments are represented by schematized catenes consisting of conjugate facies with different high mutual position, that is, geosystemic and catenary approaches are chosen as priority (Golovanov, 1996, Brudastov, 1934).

On assessing the anthropogenic load, two groups of indicators were taken into account: direct and indirect effects on water bodies and watercourses. The indirect impact on water objects is manifested in the form of anthropogenic loads on the catchment area related to salinization of the territory, economic activities of residents, industrial or agricultural specialization of the economy. The indicators characterizing these factors were used for zoning (ranking) of the Karatal river basin area according to the degree of anthropogenic load.

The following data were used as main (basic): the population density in the catchment area, the density of industrial production (the volume of industrial output in the region in thousands dollars per $1 \mathrm{~km}^{2}$ ) and agricultural development including (\% arable land) and livestock load (Livestock Units -LSU per $1 \mathrm{~km}^{2}$ ).

The used indicators were grouped according to the types of anthropogenic influences: demographic, industrial and agricultural. The agricultural load is obtained as the arithmetic mean of the scores of the intensity use of land (plowing) and livestock loads. The aggregate anthropogenic load was defined as the arithmetic mean of the scores of the demographic, industrial and agricultural load which is based on the methodology of Isachenko, (2001). Table 1 shows the scale of integral criteria for assessing the man-caused load of the natural system, including population density, density of industrial production, level of use of land resources for agriculture, that is, plowing and livestock load.

Table 1. Scale of main indicators for zoning of the territory according to the degree of anthropogenic load (Isachenko, 2001).

\begin{tabular}{|c|c|c|c|c|}
\hline \multirow[b]{2}{*}{$\begin{array}{l}\text { The intensity of the load, } \\
\text { scores }\end{array}$} & \multicolumn{4}{|c|}{ Indicators } \\
\hline & $\begin{array}{l}\text { Population } \\
\text { density } \\
\text { people } / \mathrm{km}^{2}\end{array}$ & $\begin{array}{l}\text { Density of industrial production, } \\
\text { thousand dollars } / \mathrm{km}^{2}\end{array}$ & $\begin{array}{l}\text { Arable lands } \\
\text { (\% of plowed land) }\end{array}$ & $\begin{array}{l}\text { Livestock Units } \\
\text { (LSU) per } 1 \mathrm{~km}^{2}\end{array}$ \\
\hline Minor or missing (1) & 0.00 & 0.00 & 0.00 & 0.00 \\
\hline Very low (2) & $<0.10$ & $<0.35$ & $<0.10$ & $<0.10$ \\
\hline Low (3) & $0.11-1.00$ & $0.36-3.50$ & $0.11-1.00$ & $0.11-1.00$ \\
\hline Moderate (4) & $1.10-1.50$ & $3.60-35.00$ & $1.10-5.00$ & $1.10-2.00$ \\
\hline Average (5) & $5.10-10.00$ & $36.00-105.00$ & $5.10-15.00$ & $2.10-3.00$ \\
\hline Significant (6) & $11.0-25.00$ & $106.00-140.00$ & $15.10-40.0$ & $3.10-6.00$ \\
\hline High (7) & $25.10-50.0$ & $141.0-170.0$ & $40.1-60.0$ & $6.10-10.0$ \\
\hline Very high (8) & $>50.0$ & $>170.00$ & $>60.0$ & $>10.00$ \\
\hline
\end{tabular}

\section{Geomorphological analysis of catchment basins of Karatal River}

The geomorphological schematization of the catchment area of the basin of river Karatal was made on the basis of the methodological approach of Golovanov (1993) and is due to the lithological basis and position, which are characterized 
by heterogeneity in the hydrological regime in the features of the formation of soil-vegetation cover within the ecosystems of its tributaries which depend on the natural and climatic conditions of the region (Mustafaev at al., 2015).

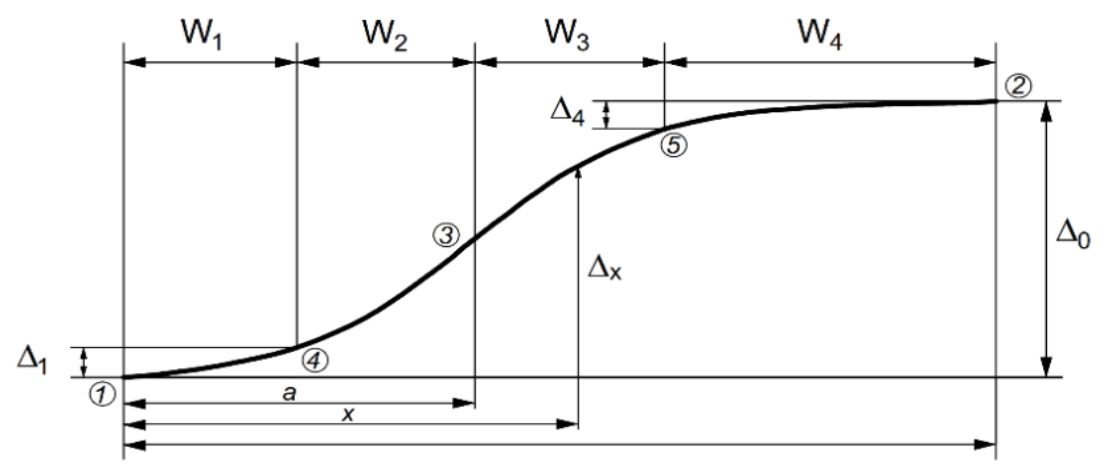

Figure 1. Geomorphological schematization of the landscape catena

(W - the width of the landscape catena $W_{4}, W_{3}, W_{2}$, and $W_{1}$ - respectively the extent of the eluvial, transeluvial, trans-accumulative and superaquatic elementary landscapes; $\Delta_{1}$ and $\Delta_{4}$ - the height differences of the superaquatic and eluvial elementary landscapes respectively, 1, 2, 3, 4, 5characteristic points), (Golovanov, 1993).

The catenary approach is the basis for the geomorphological schematization of the catena in support of the need for reclamation of the watersheds of the Karatal river basin, that is, the catchment area is represented by a set of catenes by the number of equal physical and geographical areas in the catchment area (Fig. 1). The geomorphological scheme of the catena consists of four facies with different altitude mutual positions, that is, the eluvial facies represent elevation in the watershed lines, and the transeluvial facies represent the slope to the point of inflection, the trans-accumulative represent the slope after the inflection point, the superaquatic facies represent the lowland of the above-floodplain terraces. The transeluvial and trans-accumulative facies form the transit facies of the slope, and the superaquatic facies adjoins the watercourse. Such a schematization differentiates the facies by the type of water supply, that is, takes into account the size and shape of the relief it represents the catena, as an elementary catchment area with its characteristic features (Mustafaev at al., 2015).

The mountainous, foothill, foothill flat and flat landscape zones are distinguished on the territory of the catchments of the Karatal river basin which differ in the sum of biologically active temperatures $\left(\mathrm{t}^{\circ} \mathrm{C}\right)$, atmospheric precipitation $(P$ $m m)$, evaporation $\left(E_{o} \mathrm{~mm}\right)$ and photosynthetically active radiation $\left(R \mathrm{~kJ} / \mathrm{s} \mathrm{m}^{2}\right)$ (Tab.2).

\section{Climate characteristics of the analyzed area.}

1. The mountainous region of the Zhungarian Alatau (eluvial facies), where the hydrothermal coefficient (HTC) is $<0.70$ with a sum of air temperature above $10^{\circ}$ is less than $2800^{\circ} \mathrm{C}$.

2. A very arid, foothill zone (transeluvial facies) with hydrothermal coefficient (HTC) is $0.50-0.70$ and a sum of temperature above $10^{\circ}$ equal to $2800-3200^{\circ} \mathrm{C}$.

3. Dry moderate zone (trans- accumulative facies), where the hydrothermal coefficient (HTC) is $0.30-0.50$ with the sum of the air temperature above $10^{\circ} \mathrm{C}$ equal to $3200-3500^{\circ} \mathrm{C}$.

4. Very dry zone (superaquatic facies), where the hydrothermal coefficient (HTC), which characterizes the moisture and heat availability $-0.20-0.30$ with a sum of air temperature above $10^{\circ}$ is equal to $3200-3500^{\circ} \mathrm{C}$.

Table 2. Physico-geographical zoning of the Karatal river basin

\begin{tabular}{|c|c|c|c|c|c|c|}
\hline \multirow[t]{2}{*}{ Meteorological station } & \multirow{2}{*}{$\begin{array}{l}\text { Elevation } \\
H, \mathrm{~m}\end{array}$} & \multirow{2}{*}{$\begin{array}{l}\text { The natural and climatic region } \\
\text { on the facies of the catchments } \\
\text { of rivers }\end{array}$} & \multicolumn{4}{|c|}{ Indicators of physical and geographical zoning } \\
\hline & & & $\begin{array}{l}P, \\
\mathrm{~mm}\end{array}$ & $\sum t^{O} C$ & $E_{O}, \mathrm{~mm}$ & $R, \mathrm{~kJ} / \mathrm{s} \mathrm{m}^{2}$ \\
\hline \multicolumn{7}{|c|}{ Mountainous class of landscapes or eluvial facies $\left(\overline{\boldsymbol{W}}_{4}\right)$} \\
\hline Kugaly & 1365 & Mountainous & 350 & 2250 & 675 & 149.0 \\
\hline Kos-Agash & & Mountainous & 345 & 2300 & 690 & 150.8 \\
\hline \multicolumn{7}{|c|}{ Foothill subclass of landscapes or transeluvial facies $\left(\boldsymbol{W}_{3}\right)$} \\
\hline Saryozek & 948 & Foothill & 270 & 3000 & 900 & 175.9 \\
\hline Taldygurgan & 602 & Foothill & 230 & 3100 & 930 & 179.5 \\
\hline \multicolumn{7}{|c|}{ Foothill flat subclass of landscapes or trans-accumulative facies $\left(\boldsymbol{W}_{2}\right)$} \\
\hline Ushtobe & 428 & Foothill -flat & 212 & 3180 & 954 & 182.4 \\
\hline \multicolumn{7}{|c|}{ The flat class of landscapes or superaquatic facies $\left(\boldsymbol{W}_{l}\right)$} \\
\hline Naimensuiek & 349 & flat & 195 & 3200 & 960 & 183.0 \\
\hline
\end{tabular}

On the basis of Tab. 2 the geomorphological schematization of the catchment area of the Karatal River basin was developed from the eluvial $\left(\boldsymbol{W}_{4}\right)$ to the suberaquatic facies $\left(\boldsymbol{W}_{1}\right)$, where the altitude of their location gradually decreases, which makes it possible to base them on the basis of geomorphological schematization of the landscape catenes of the catchment area (Table 3).

As it can be seen from Table 3 the above given catchment classification of the Karatal basin river as a whole coincides with natural-climatic and landscape zoning, that is, the first classification relies on relative values (for example: the degree of moistening) and the second is on absolute values (for example, the land relief). Because of this, small 
inconsistencies between classifications are observed and it is necessary to determine the main classification (Golovanov et all., 2006, Aidarov 2007, Zhanymkhan et all.,2016).

Table 3. Geomorphological schematization of landscape catchment area of the Karatal river basin

\begin{tabular}{|l|l|l|l|}
\hline Natural and climatic zones & $\begin{array}{l}\text { Geomorphological indicator (absolute } \\
\text { height of the earth's surface, } \mathrm{m})\end{array}$ & Administrative districts \\
\hline Class of landscape & Facies & $<1400$ & $\begin{array}{l}\text { Kerbulak region } \\
\text { Koksu region }\end{array}$ \\
\hline Mountainous & Eluvial $\boldsymbol{W}_{\mathbf{4}}$ & $600-1400$ & $\begin{array}{l}\text { Kerbulak region } \\
\text { Eseldy region } \\
\text { Koksu region }\end{array}$ \\
\hline Foothill & Transeluvial $\boldsymbol{W}_{\mathbf{3}}$ & & $\begin{array}{l}\text { Eseldy region } \\
\text { Karatal region }\end{array}$ \\
\hline Foothill -flat & $\begin{array}{l}\text { Trans-accumulative } \\
\boldsymbol{W}_{\mathbf{2}}\end{array}$ & $450-600$ & Karatal region \\
\hline
\end{tabular}

Due to the climatic heterogeneity of the territory and the mountain-plain relief the soil cover of the Karatal basin is very diverse. The natural and climatic indicators of catchments are characterized by: hydrothermal coefficient $\left(H T C=10 \cdot P / \sum t\right)$, coefficient of moistening $\mathrm{C}_{\mathrm{m}}\left(C m=P / E_{o}\right)$, moisture assessment $\left(C_{a}=P / 0.18 \sum t\right)$, dryness index $(\bar{R}=R / L \cdot P)$, biological and climatic productivity $\left(B C P=C_{m}\left(\sum t / 1000\right)\right.$.

As it can be seen from Table 4, the Karatal River basin has enough high heat supply, since $H T C=0.60-1.55$ and $\bar{R}$ $=1.71-3.75$ are quite high. However, the moisture availability of the basin is very low $\left(C_{m}=0.20-0.52\right)$, which determines the peculiarity of the formation and functioning of landscape systems.

Table 4. Hydrological-climatic assessment of heat and moisture availability of the Karatal River basin

\begin{tabular}{|c|c|c|c|c|c|c|}
\hline \multirow[t]{2}{*}{ Meteorological station } & \multirow{2}{*}{$\begin{array}{l}\text { Elevation } \\
H, \mathrm{~m}\end{array}$} & \multicolumn{5}{|c|}{ Average annual for a long-term period } \\
\hline & & $\bar{R}$ & $H T C$ & $B C P$ & $C_{m}$ & $C_{a}$ \\
\hline \multicolumn{7}{|c|}{ Mountainous class of landscapes or eluvial facies $\left(\boldsymbol{W}_{\mathbf{4}}\right)$} \\
\hline Kugaly & 1365 & 1.71 & 1.55 & 1.17 & 0.52 & 0.86 \\
\hline Kos-Agash & 1300 & 1.75 & 1.50 & 1.15 & 0.50 & 0.83 \\
\hline \multicolumn{7}{|c|}{ Foothill subclass of landscapes or transeluvial facies $\left(\boldsymbol{W}_{3}\right)$} \\
\hline Saryozek & 948 & 2.50 & 0.9 & 0.90 & 0.30 & 0.50 \\
\hline Taldykorgan & 602 & 3.12 & 0.7 & 0.78 & 0.25 & 0.43 \\
\hline \multicolumn{7}{|c|}{ Foothill flat subclass of landscapes or trans-accumulative facies $\left(\boldsymbol{W}_{2}\right)$} \\
\hline Ushtobe & 428 & 3.44 & 0.7 & 0.70 & 0.22 & 0.37 \\
\hline \multicolumn{7}{|c|}{ Flat class of landscapes or superaquatic facies $\left(\boldsymbol{W}_{\boldsymbol{I}}\right)$} \\
\hline Naimensuek & 349 & 3.75 & 0.6 & 0.64 & 0.20 & 0.34 \\
\hline
\end{tabular}

The classification according to natural - climatic parameters is more suitable for a complex arrangement, combining the catchments and their catenes into the same type of landscape groups by the most significant indicators for heat and moisture availability $R=5-6$. According to this classification, it is necessary to carry out the justification of melioration of agricultural lands and the optimization of the catchment infrastructure with their complex arrangement of the Karatal river basin.

\section{RESULTS OF THE RESEARCH}

In the catchment basin area of the Karatal river there are four districts of Almaty region, they are: Eskeldy, Kerbulak, Koksu and Karatal with a total area of 4669056 ha and a population of 191279 people (Table 5) (Statistical Yearbook, 2012).

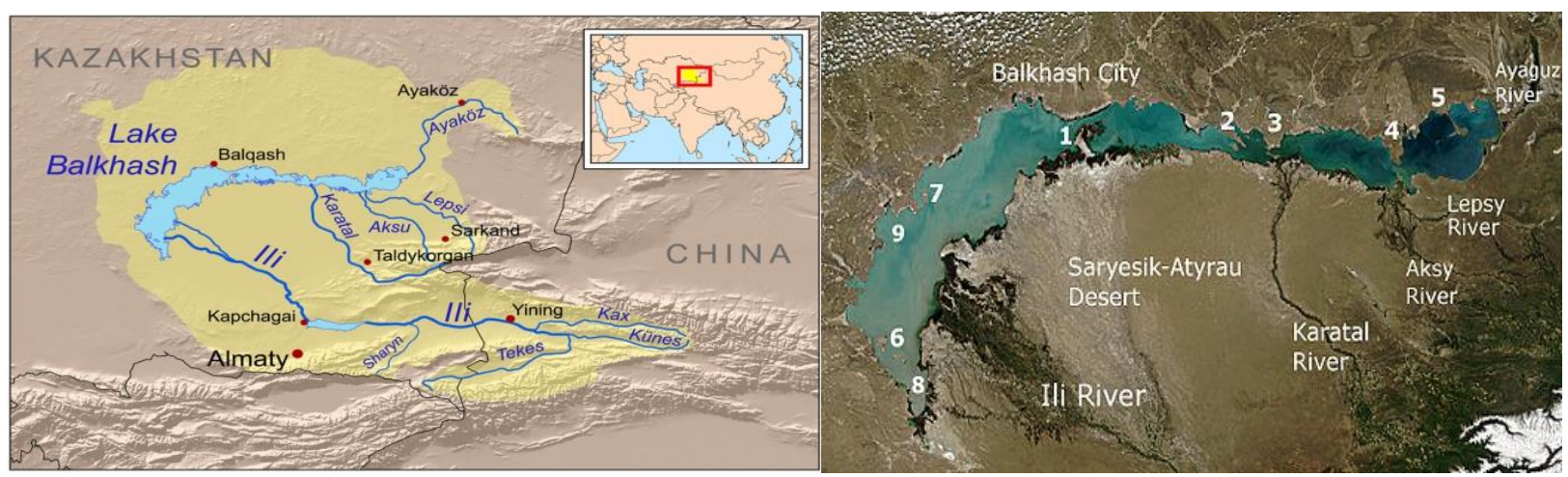

Figure 2 Map of the Lake Balkhash drainage basin with Karatal river. https://en.wikipedia.org/wiki/Lake_Balkhash 


\section{Proceedings of the $8^{\text {th }}$ International Scientific Conference Rural Development 2017}

Taking into account the natural-climatic conditions of landscape systems, the main agricultural crops are cultivated to meet the needs of the population in the basin of the Karatal river (Table 6) (Statistical Yearbook 2012). As it can be seen from Table 6, the main areas of agricultural land are occupied by wheat and barley with a total area of 118600 hectares of which about 101000 hectares of rainfed lands are located in the foothills of the Eskeldy and Kerbulak districts of Almaty region.

Table 5. Total land area and distribution of agricultural land in the Karatal river basin

\begin{tabular}{|c|c|c|c|c|c|c|}
\hline \multirow{2}{*}{$\begin{array}{l}\text { Administrative } \\
\text { districts }\end{array}$} & \multirow{2}{*}{$\begin{array}{l}\text { Population } \\
\text { (number of people) }\end{array}$} & \multirow{2}{*}{$\begin{array}{l}\text { Total land area, } \\
\text { ha }\end{array}$} & \multirow{2}{*}{$\begin{array}{l}\text { Agricultural } \\
\text { land, ha }\end{array}$} & \multicolumn{3}{|c|}{ Including } \\
\hline & & & & arable land & $\begin{array}{l}\text { meadows } \\
\text { hayfields }\end{array}$ & pastures \\
\hline Eskeldy & 50436 & 803730 & 580002 & 55968 & 16035 & 506276 \\
\hline Kerbulak & 51894 & 1116575 & 922628 & 130549 & 19988 & 761351 \\
\hline Koksu & 40286 & 697704 & 650657 & 31549 & 9308 & 599039 \\
\hline Karatal & 48663 & 2051047 & 1792228 & 19964 & 14342 & 1753855 \\
\hline Total & 191279 & 4669056 & 3945515 & 238030 & 59673 & 3620521 \\
\hline
\end{tabular}

The soybean area prevails in irrigated lands which in the basin of the Karatal River is about 19100 hectares, as well as vegetable crops with a total area of 9700 ha. At the same time, one of the water-intensive crops - rice is cultivated on the territory of the Karatal district with an area of 4100 hectares, which shows a certain balance in the structure of agricultural lands of the Karatal river basin. However, the productivity of agricultural crops is relatively low, which requires the need for improving the technology of cropping (Table 7) (Statistical Yearbook, 2012) .

Table 6. Crop area and structure of agricultural crops which are cultivated in the Karatal river basin

\begin{tabular}{|l|l|l|l|l|l|}
\hline \multirow{2}{*}{ Crops } & \multicolumn{2}{|l|}{ Administrative regions which are located in the Karatal river basin, ha } & Karatal river basin \\
\cline { 2 - 6 } & Eskeldy region & Kerbulak region & Koksu region & Karatal region & 3700 \\
\hline Wheat & 12000 & 28400 & 7600 & 1100 & 51700 \\
\hline Barley & 13500 & 47100 & 5200 & 700 & 2100 \\
\hline Corn for grain & 800 & 300 & 300 & 4100 & 4100 \\
\hline Rice & - & - & - & 200 & 1500 \\
\hline Sunflower & 900 & 100 & 300 & 1000 & 19100 \\
\hline Soybean & 10400 & - & 7700 & 400 & 4100 \\
\hline Sugar beet & 1000 & - & 2700 & 1100 & 6600 \\
\hline Potatoes & 2200 & 2400 & 900 & 1500 & 3700 \\
\hline Vegetables & 900 & 500 & 800 & 13800 & 158990 \\
\hline Total & 40890 & 78800 & 25500 & & \\
\hline
\end{tabular}

The livestock breeding has developed in the basin of the river Karatal, which has certain natural resources, that is, in these regions there are hayfields and pastures that ensure their livelihoods (Table 8) (Statistical Yearbook,2012)..

Table 7. Productivity of agricultural crops in the Karatal river basin

\begin{tabular}{|l|l|l|l|l|l|}
\hline \multirow{2}{*}{ Crops } & Administrative regions which are located in the Karatal river basin, tons/ha & Karatal river basin \\
\cline { 2 - 6 } & Eskeldy region & Kerbulak region & Koksu region & Karatal region & 20.9 \\
\hline Wheat & 24.0 & 17.8 & 24.7 & 17.0 & 20.1 \\
\hline Barley & 23.1 & 18.3 & 23.7 & 15.3 & 51.8 \\
\hline Corn for grain & 57.4 & 37.0 & 60.8 & 52.0 & 38.5 \\
\hline Rice & - & - & - & 38.5 & 13.4 \\
\hline Sunflower & 11.2 & 12.3 & 13.0 & 17.3 & 17.9 \\
\hline Soybean & 19.2 & - & 21.3 & 13.2 & 237.9 \\
\hline Sugar beet & 329.4 & - & 267.1 & 267.1 & 184.5 \\
\hline Potatoes & 164.4 & 193.6 & 193.0 & 187.0 & 257.1 \\
\hline Vegetables & 184.2 & 241.2 & 318.0 & 285.0 & \\
\hline
\end{tabular}

As it can be seen from Table 8, the livestock load is mainly distributed unevenly across the territory of the districts, that is, despite the large enough occupied total area and including pasture land, the smallest number of animals is observed in the Karatal region.

Table 8. Livestock animals in the Karatal river basin

\begin{tabular}{|l|l|l|l|l|l|}
\hline \multirow{2}{*}{ Types of animals } & \multicolumn{4}{l}{ Administrative regions which are located in the Karatal river basin, heads } & Karatal river basin \\
\cline { 2 - 6 } & Eskeldy region & Kerbulak region & Koksu region & Karatal region & (2800 \\
\hline Cattle & 26700 & 22800 & 30800 & 44600 & 124900 \\
\hline Dairy cows & 13800 & 21600 & 11800 & 12000 & 59200 \\
\hline Pigs & 4600 & 1200 & 4200 & 9100 & 19100 \\
\hline Sheep and goats & 112500 & 200000 & 128900 & 81500 & 522900 \\
\hline Horses & 7100 & 13500 & 8600 & 6600 & 35800 \\
\hline Total & 164700 & 259100 & 184300 & 153800 & 761900 \\
\hline
\end{tabular}


In connection with the existing systems of nature management with primary development of mining, which mainly from the volume of industrial production in the Karatal basin (Tab. 9) (Statistical Yearbook, 2012).

Based on the data given in Tables 5-9, the calculations were carried out in the Karatal river basin, which revealed the following differentiation of the natural and anthropogenic loads. By Isachenko (2001) criterion, a large enough drop is obtained on the scale and it is very difficult to determine accurately, therefore we took the maximum values of the environment of the 4 indicators themselves (Table 10).

Table 9. The volume of industrial and agricultural production by main activities in the Karatal river basin

\begin{tabular}{|l|l|l|l|l|l|}
\hline \multirow{2}{*}{ Indicators } & \multicolumn{4}{|l|}{ Administrative regions which are located in the Karatal river basin, million tenge } \\
\cline { 2 - 6 } & $\begin{array}{l}\text { Eskeldy } \\
\text { region }\end{array}$ & $\begin{array}{l}\text { Kerbulak } \\
\text { region }\end{array}$ & $\begin{array}{l}\text { Koksu } \\
\text { region }\end{array}$ & $\begin{array}{l}\text { Karatal } \\
\text { region }\end{array}$ & Karatal river basin \\
\hline Gross agricultural production: & 11893.1 & 14099.3 & 9249.2 & 10265.0 & 45506.6 \\
\hline - plant production & 7362.8 & 8039.3 & 5549.7 & 6667.5 & 27619.3 \\
\hline - animal husbandry & 4608.4 & 6073.2 & 3703.2 & 3706.6 & 18091.4 \\
\hline Mining industry & 15.5 & 656.7 & 23.7 & 34.8 & 730.7 \\
\hline Manufacturing industry & 4455.9 & 407.4 & 3510.8 & 1708.9 & 10083.0 \\
\hline Other production & 4387.8 & 6.2 & 3061.7 & 1394.8 & 8850.5 \\
\hline Total & 32723.5 & 29282.1 & 25098.3 & 23777.6 & 110881.5 \\
\hline
\end{tabular}

The moderate (4) anthropogenic load (4 points) is observed in the territory of the Karatal district of Almaty region, where the density of population is 0.237 people $/ \mathrm{km}^{2}$, the density of industrial production is 0.342 thousand dollars $/ \mathrm{km}^{2}$. The territory is characterized by the lowest for the considered basin with agricultural assimilation with a level of plowing $0.007 \%$ and livestock load of about $0.750 \mathrm{LSU} / \mathrm{km}^{2}$.

Table 10. Indicators of anthropogenic loads in the catchment basin of the river Karatal

\begin{tabular}{|c|c|c|c|c|c|}
\hline \multirow[t]{2}{*}{ Indicators } & \multicolumn{5}{|c|}{$\begin{array}{l}\text { Indicators of anthropogenic loads in the catchment basin of the river Karatal } \\
\text { Final scores of evaluation of the intensity of the load/number of points for selected } \\
\text { indicators (results of evaluation in brackets). }\end{array}$} \\
\hline & $\begin{array}{l}\text { Eskeldy } \\
\text { region }\end{array}$ & $\begin{array}{l}\text { Kerbulak } \\
\text { region }\end{array}$ & $\begin{array}{l}\text { Koksu } \\
\text { region }\end{array}$ & $\begin{array}{l}\text { Karatal } \\
\text { region }\end{array}$ & $\begin{array}{l}\text { Karatal river } \\
\text { basin }\end{array}$ \\
\hline Total area, $\mathrm{km}^{2}$ & 80373 & 111657.5 & 69770.4 & 205104.7 & 466905.6 \\
\hline Population, people/person & 50436 & 51894 & 40286 & 48663 & 191279 \\
\hline Population density, people $/ \mathrm{km}^{2}$ & $0.530(3)$ & $0.460(3)$ & $0.577(3)$ & $0.237(3)$ & $0.410(3)$ \\
\hline Area of irrigated land, ha & 40890 & 78800 & 25500 & 13800 & 158990 \\
\hline$\%$ of plowed land & $0.050(2)$ & $0.070(2)$ & $0.036(2)$ & $0.007(2)$ & $0.034(2)$ \\
\hline Livestock load, LSU/km² & $2.050(5)$ & $2.320(5)$ & $2.542(5)$ & $0.750(3)$ & $1.532(4)$ \\
\hline $\begin{array}{l}\text { Density of industrial production, thousand } \\
\text { dollars } / \mathrm{km}^{2}\end{array}$ & $1.192(3)$ & $0.767(3)$ & $1.064(3)$ & $0.342(2)$ & $0.703(2)$ \\
\hline Located water resources, $\mathrm{km}^{3}$ & 0.381 & 0.363 & 1.166 & 0.380 & 2.29 \\
\hline $\begin{array}{l}\text { Specific water availability per inhabitant, } \\
\text { thousand } \mathrm{m}^{3} / \text { person }\end{array}$ & 7.566 & 6.395 & 23.943 & 7.308 & 11.972 \\
\hline
\end{tabular}
maximum value).

The average anthropogenic load (5 points) is typical for the largest group, which includes the Eskeldy, Kerbulak and Koksu districts, where the population density is $0.460-0.577$ people $/ \mathrm{km}^{2}$, the density of industrial production varies from $0.767-1.192$ thousand dollars $/ \mathrm{km}^{2}$, the level of plowing from 0.005 to $0.034 \%$, livestock load from 2.050 to 2.542 $\mathrm{LSU} / \mathrm{km}^{2}$.

\section{SUMMARY AND CONCLUSIONS}

The methodology for assessing pressure on water resources presented in works resulting from both natural conditions and business activities in the catchment (both agricultural and industrial) may allow making rational decisions regarding the development directions of the catchment areas. Of course, the authors are aware of the imperfection of the methodology resulting primarily from the use of many statistical information, as well as meteorological and hydrological information. The analyzed area, due to its specificity (freshwater and saltwater in Lake Balkhash, cross-border nature of rivers flowing into the lake) requires a special approach. However, the methodology presented in the work can be used in other areas. Of course, we can argue about the ranges and volumes of data used, but the methodology can be universalized and applied in other areas. Depending on the general statements and wording contained above, the following more specific conclusions can be made:Based on the use of statistical materials of the Almaty region of the Republic of Kazakhstan using the scale of the main indicators for the zoning of the territory in terms of the degree of anthropogenic load, the proposed methods was carried out in the catchment area of the Karatal basin in the context of administrative districts to estimate the man-caused loads. At the same time, the level of anthropogenic load is determined by the maximum quantitative values of the scale of the main indicators for the types of anthropogenic load. 
2. For a comprehensive arrangement, the classification according to natural and climatic indicators is more suitable, combining watersheds and their catens into similar landscape groups by the most significant indicators for heat and moisture availability. According to this classification, it is necessary to carry out the justification of land reclamation and the optimization of the catchment infrastructure in the complex development of the Karatal river basin.

3. Generally, according to the geoecological load, as a result of the anthropogenic activities of the Karatal river basin, it is not high, that is, the basin belongs to the region with not a high anthropogenic load. In general, the Karatal river basin has fairly high water availability, but it is characterized by a high degree of contamination, both locally and regionally, due to the development of mining and manufacturing industries. The aggregate anthropogenic load on the territory of the Karatal river basin increases downstream of the rivers reaching the greatest values in the mouths of Lake Balkhash

4. At present, we want to develop a system of models that combine 4 indicators and based on Isachenko (2002) integral criteria, that is, the scale of integral criteria for assessing the man-made load of the natural system will have certain quantitative values.

\section{REFERENCES}

1. Aidarov I. P. 2007. Complex development of lands. - Moscow, MSPU [In Russian].

2. Burlibaev M.Zh., Fascevskij B.V., Opp K., Burlibaeva D.M., Kajdarova R.K., Vagapova A.R., 2014. Naucnye osnowy normirovanija ekologiczeskogo stoka rek Kazakhstana. Kaganat, Almaty [In Russian].

3. Brudastov A.D. 1934. Dehumidification of mineral and marsh lands. Moscow,: Agriculture [In Russian].

4. Golovanov, A.I., Suhkarev, Yu.I., Shabanov, V.V. 2006. Complex development of territories- a further stage of land melioration. Melioration and Water Economy, Vol. 2, pp. 25-31.

5. Isachenko, A.G. 2001. Ecological geography of Russia. St. Petersburg State University [In Russian].

6. Golovanov, A. I. 1993. Melioration of landscapes. Melioration and Water Management, Vol. 3, pp. 6-8 [In Russian].

7. Kaca, E., 2017. Methodology of assessing the relative environmental validity of developing drainage and irrigation on a regional scale. Journal of Water and Land Development, Vol. 35, pp. 101-112. https://doi.org/10.1515/jwld-2017-0073

8. Khafizov, A.R., Khazipova, A.F., Shakirov, A.V. 2000. Geomorphological analysis of the flat watersheds of Western Bashkortostan with their complex arrangement. Problems of Regional Ecology, pp. 125-129.

9. Mustafaev, Zh.S., Kozykeeva, A.T., Zhanymkhan, K. 2015. Geomorphological analysis of catchment area of the Karatal river basin. Proceedings of the international scientific and practical conference dedicated to the $85^{\text {th }}$ Anniversary of the KazNAU. Vol. IV, pp. 34-38.

10. Mustafaev, Zh.S.2016. Ecological justification land improvement of areas used for agriculture. Academic Publishing RU LAP LAMBERT.

11. Ryden, L., Mosiej, J., Karczmarczyk, A., 2017. The Sciences of Agriculture Reclamation. In: Agricultural Water Management and Irrigation. The Baltic University Programme, Uppsala University, pp. 39-49.

12. Sommer, M., Halm, D., Weller, U., Zarei, M., Stahr, K., 2000. Lateral podzolization in a granite landscape. Soil Science Society of America Journal, Vol. 64, Iss. 6, 2069.

13. Statistical Yearbook of the Almaty region (2011). 2012. The real sector of the economy. Almaty, pp. 199-332.

14. Stoyasheva, Kh.V., Rybkina, I.D. 2013. Transboundary problems of nature management in the Irtysh basin. Geography and Natural Resources, Vol. 1, pp. 26-32.

15. Zhanymkhan, K., Mustafaev, Zh.S., Kozykeeva, A.T. 2016. Natural potential of catchment area of Karatal basin river. Proceedings of the International Scientific and Practical Conference of Young Scientists, Vol. 1, pp. 192-195. Almaty.

16. Young, A. 1972. The soil catena: a systematic approach. International Geoma hvn, No. 22, pp. 287-289.

17. Yunussova, G., Mosiej, J. 2016. Transboundary water management priorities in Central Asia countries - Tobol River case study in Kazakhstan. Journal of Water and Land Development. Vol. 31, pp. 157-167. https://doi.org/10.1515/jwld-2016-0047 